\title{
Kritické myslenie ako dôležitá súčast' kurikulárnej reformy na Slovensku: Skúmanie fenoménu v slovenskej časopiseckej literatúre ${ }^{1}$
}

\author{
Martina Kosturková, Janka Ferencová, \\ Valentína Šut'áková \\ Prešovská univerzita v Prešove, FHPV, Ústav pedagogiky, andragogiky a psychológie
}

\begin{abstract}
Abstrakt: Kurikulárna reforma, ktorá bola na Slovensku oficiálne uvedená do edukačnej praxe škôl prijatím nového Zákona č. 245/2008 Z. z. o výchove a vzdelávaní (školský zákon), oficiálne vytvorila priestor aj pre rozvoj kritického myslenia. Jeho dôkladné skúmanie je jedným z predpokladov pre efektívnejšie rozvíjanie uvedenej spôsobilosti v edukačnej praxi škôl. Prehl'adová štúdia sa zameriava na ukotvenie problematiky v odbornej oblasti na Slovensku. Cielom je integrovat' doterajšie poznatky a analyzovat' stav bádania za obdobie 2008-2017 v slovenskej časopiseckej literatúre. Metodológia vychádza z odporúčaní Mareša (2013) o systematickom mapovaní príspevkov $(n=72)$ v oblasti kritického myslenia. Za najväčší nedostatok považujeme absenciu empirických a experimentálnych štúdií v relevantných vedeckých časopisoch. Navyše z kritickej analýzy príspevkov vyplýva, že aj po vyše desat’ročnom avizovaní o nutnej potrebe rozvoja kritického myslenia, ako spôsobilosti budúcnosti, v slovenskej edukácii je jej pozornost' stále na periférii.
\end{abstract}

Klúčové slová: kurikulárna reforma, kritické myslenie, analýza časopiseckých príspevkov

\section{Critical Thinking as an Important Part of the Curriculum Reform in Slovakia: Examining the Phenomenon in the Slovak Journals}

Abstract: The curriculum reform in Slovakia, which was officially put into educational practice of schools by adopting the new Act No. 245/2008 Coll. on Upbringing and Education (The School Act) has also officially created space for the development of critical thinking. Thorough examination is one of the prerequisites for more effective development of the mentioned capability in the educational practices in schools. The review study focuses on specification of the issue in the professional area in Slovakia. The aim is to integrate the hitherto gained knowledge and to analyze the state of the research in 2008-2017 in the Slovak academic journals. The methodology is based on Mareš's advice (2013) on systematic mapping of articles $(n=72)$ in the areas of critical thinking. However, the most significant shortcoming is considered the absence of empirical and experimental studies in relevant scientific journals. In addition to this, the critical analysis of the articles show that in spite of more than ten years of urging for the development of critical thinking as the capability of the future, its position in the Slovak education system is still peripheral.

Keywords: curriculum reform, critical thinking, analysis of journal contributions

1 Prehl'adová štúdia je výstupom projektu VEGA č. 1/0382/16 s názvom Inovatívna kultúra školy ako učiacej sa organizácie. 
2 Zmena politického režimu na Slovensku po roku 1989 vyvolala potrebu zaoberat' sa spôsobom fungovania školstva a vytvorila priestor pre zavádzanie inovácií do vzdelávacieho systému. Jednou z významných myšlienok reformy bola orientácia vzdelávania na rozvoj tzv. klúčových spôsobilostí či prenositelných zručností 21. storočia, medzi ktoré patrí napr. kritické, tvorivé myslenie, komunikatívne a d'alšie sociálne spôsobilosti. Ich formovanie $v$ procese školskej edukácie predpokladalo viaceré systémové zmeny, ku ktorým však nedošlo. Ako významný je potrebné spomenút' aj fakt, že následkom nesystémových krokov, rýchleho striedania vlád a pod., dochádzalo k ochabnutiu entuziazmu učitelov. Od učitel'a sa očakávala nová rola ako tvorcu kurikula, na ktorú nebol pripravený (Kosová, 2017; Orosová \& Klimková, 2016; Pavlov \& Šnídlová, 2013; Rovňanová, 2015). Dalo sa preto predpokladat', že v praxi dôjde len k formálnym inováciám, bez skutočnej zmeny. Uvedené sa nevyhnutne premietlo do nie príliš pozitívneho stavu nášho školstva a negatívnych výsledkov žiakov slovenských škôl $\checkmark$ klúčových oblastiach, ktoré by mali byt' podla oficiálnych dokumentov rozvíjané. Jednou z nich je aj kritické myslenie, ktorého význam je deklarovaný v rôznych národných i medzinárodných dokumentoch, Štátny vzdelávací program SR nevynímajúc.

$\checkmark$ tomto kontexte považujeme za potrebné uviest' podstatné súvislosti vývoja kritického myslenia na Slovensku aj pred rokom 2008. Problematiku je potrebné vnímat' komplexnejšie. Nie je možné odtrhnút' sledované obdobie od celkového kontextu. Prvotné vízie podpory rozvoja kritického myslenia na Slovensku boli iniciované zdola (na mikroúrovni) začiatkom 90. rokov 20. storočia, kde sa učitelia od materských až vysokých škôl združovali okolo mimovládnych organizácií. Tie zastrešovali medzinárodné projekty smerujúce $k$ ovplyvňovaniu edukačných stratégií učitelov (Porubský et al., 2014). Známy je projekt Orava - IOWA z roku 1994 pre zavádzanie konštruktivisticky orientovaného vyučovacia prevažne $v$ základných a stredných školách. Následkom týchto vplyvov v roku 1994 Ministerstvo školstva iniciovalo tvorbu projektu Konštantín (Ministerstvo školstva a vedy SR, 1994) kde okrem iného dokument požaduje, aby 15-20 \% učiva bolo venovaných rozvoju hodnotiaceho a tvorivého myslenia (Ministerstvo školstva a vedy SR, 1994). Jedným z prvých záujmov o problematiku kritického myslenia v SR bol grant v roku 1994 (Kolláriková, 1995). Išlo prevažne o teoretické spracovanie problematiky pracovníkmi Pedagogickej fakulty Univerzity Komenského v Bratislave spolu s odborníkmi z Univerzity v Severnej lowe ${ }^{2}$, ked’že tomuto druhu myslenia sa na poli vedy a školskej praxe na Slovensku nevenovala žiadna pozornost'. Ďalšie vízie vyústili v projekte Milénium (Turek, Zelina, \& Rosa, 2000). Za toto obdobie nachádzame minimum odborných poznatkov k problematike kritického myslenia (napr. Gavora, 1995; Petrasová, 2000).

Školským zákonom z roku 2008 bola kurikulárna reforma na Slovensku oficiálne uvedená do edukačnej praxe škôl s cielom naštartovat' zmeny, ktoré by viedli aj k podpore kritického myslenia. Od učitel’ov sa $v$ tomto smere očakávala nová rola ako spolutvorcov kurikula, na ktorú však neboli pripravení. Ligoš (2008) konštatoval,

2 Spomenieme autorov, ktorí podporili myšlienku výchovy ku kritickému mysleniu medzi prvými na Slovensku: Z. Kolláriková, P. Gavora, M. Lapitka, Kurtis S. Meredith, Jeannie L. Steeleová a M. Zelina (ako recenzent a odborný poradca v oblasti inovovania edukácie). 
že v intenciách rozvoja klúčových kompetencií pre celoživotné vzdelávanie človeka

v 21. storočí sa pri dosahovaní hlavných cielov (napr. primárneho, sekundárneho, vyššieho sekundárneho gymnaziálneho vzdelávania) predpokladá používanie tých učebných postupov a prístupov, ktoré podporujú rozvoj kritického myslenia (ŠPú, 2015a). Rovnako sú v profile absolventa jednotlivých stupňov vzdelávania premietnuté kompetencie aj vo vzt’ahu ku kritickému mysleniu. Napr. absolvent vyššieho sekundárneho gymnaziálneho vzdelávania dokáže kriticky zhodnotit’ informácie a ich zdroj, tvorivo ich spracovat' a prakticky využívat'. Tieto kompetencie, zručnosti a schopnosti má mat' rozvinuté na úrovni svojich možností (ŠPú, 2015b). Zelina (2008) poznamenáva, že jednou zo základných zásad reformy školstva je komplexný rozvoj poznávacích funkcií žiaka, kde je šest' úrovní rozvíjania poznávacích kompetencií žiaka. Na piatej úrovni je to práve oblast' kritického hodnotiaceho myslenia žiakov a v šiestej úrovni rozvoj tvorivosti žiakov. Prirodzene, že v tomto smere bolo potrebné nielen vyškolit' učitel'ov, ale aj poskytnút' im kvalitné metodické materiály.

V dôsledku chýbajúcej systémovej podpory so strany štátu postupne ochabovali snahy iniciatívnych učitel'ov o zavádzanie inovácií do vyučovacieho procesu. Uvedené sa odrazilo aj v rovine systematického teoreticko-empirického štúdia problematiky kritického myslenia.

Predkladaná prehl'adová štúdia má snahu nahliadnut' do problematiky kritického myslenia $v$ edukačnej praxi na Slovensku. Zameriava sa na skúmané komponenty $\checkmark$ pedagogicko-psychologických a didaktických poznatkoch predstavených odbornou verejnost'ou v časopiseckej literatúre na Slovensku. V poňatí zahraničných autorov ide o dlhodobo skúmaný fenomén v troch hladiskách - filozofickom, kognitívno-psychologickom a edukačno-vednom. V Slovenskej proveniencii vnímame túto problematiku skôr na periférii, aj napriek jej dlhodobým proklamáciám.

Cielom textu je hladat' odpoved' na otázku, aká pozornost' je venovaná problematike kritického myslenia $v$ časopiseckej literatúre po tom, čo sa jeho rozvoj oficiálne zaviedol do Štátneho vzdelávacieho programu ako jedna z ciel'ových požiadaviek v edukácii. Predmetom záujmu bola identifikácia tematiky, charakter a oblast' skúmania, diagnostika stavu kritického myslenia edukantov a edukátorov, identifikácia bariér a možností rozvoja kritického myslenia a experimentálne zásahy v skúmanej oblasti. Predmetom analýzy boli práce teoretického, empirického a aplikačného charakteru publikované v odborných a vedeckých domácich časopisoch za posledných desat' rokov.

\section{Kritické myslenie ako pojem}

Pojem kritické myslenie je odvodený z koreňov starovekého Grécka: kriticos (čo znamená v každom rozsudku) a kriterion (čo znamená normu). Etymologicky slovo znamená vytváranie kritického úsudku založeného na normách (Paul \& Elder, 2003). Vývoj problematiky kritického myslenia v základnej filozofickej rovine je badatel'ný v spisoch Sokrata, Platóna, Aristotela, Tomáša Akvinského a pod. (Center for Critical Thinking, 2006) aj v dielach novších filozofov (Ennis, 1985; Kant, 1979; Lipman, 
4 1988; Paul, 1992). Druhá línia vývoja kritického myslenia je psychologická (Bailin, 2002; Bransford \& Stein, 1984; Bruner, 1960; Feuerstein et al., 1996; Halpern, 1998; Lewis \& Smith, 1993; Sternberg, 1986); neskôr sa pridružila aj pedagogická (Bloom et al., 1956; Kennedy, Fisher, \& Ennis, 1991). To viedlo aj k rôznorodosti chápania tohto pojmu. $V$ tabul'ke 1 sú predstavené vybrané definície prevažne zahraničných odborníkov vyplývajúce z pôvodných tradícií.

Tabul'ka 1 Definície kritického myslenia vyplývajúce z pôvodnej línie - prístupu

\begin{tabular}{|c|c|c|}
\hline Línia - smer & Autor & Kritické myslenie... \\
\hline \multirow[t]{7}{*}{ Filozofický prístup } & Ennis (1985) & $\begin{array}{l}\text {... reflexné a rozumné myslenie; schopnost' zameraná na } \\
\text { to, čomu verit' alebo čo robit'. }\end{array}$ \\
\hline & Lipman (1988) & $\begin{array}{l}\text {... zručné a zodpovedné myslenie, ktoré ulahčuje dobrý } \\
\text { úsudok, pretože sa opiera o kritériá, je citlivé na kontext } \\
\text { so schopnost’ou sebaregulácie. }\end{array}$ \\
\hline & $\begin{array}{l}\text { Scriven a Paul } \\
(1987)\end{array}$ & $\begin{array}{l}\text {... intelektuálne disciplinovaný proces aktívne a šikovne } \\
\text { konceptualizovat', aplikovat', analyzovat', syntetizovat' } \\
\text { a/alebo hodnotit' informácie zhromaždené z pozorovania, } \\
\text { skúseností, úvah alebo komunikácie. Je založené } \\
\text { na univerzálnych intelektuálnych hodnotách, ktoré } \\
\text { presahujú rozdelenie predmetu: jasnost', presnost', } \\
\text { konzistencia, relevantnost', spol'ahlivé dôkazy, dobré } \\
\text { dôvody, híbka, šírka a spravodlivost'. }\end{array}$ \\
\hline & McPeck (1990) & $\begin{array}{l}\text {... schopnosti a zručnosti zapojené do činnosti aj so } \\
\text { sebareflexiou. }\end{array}$ \\
\hline & Facione (1990) & $\begin{array}{l}\text {... autoregulačný úsudok, ktorý vedie k interpretácii, } \\
\text { analýze, hodnoteniu a záverom, ako aj k vysvetleniu } \\
\text { dôkazov, koncepcií metodík, kritérií alebo kontextových } \\
\text { úvah, na ktorých je úsudok založený. }\end{array}$ \\
\hline & Paul (1992) & $\begin{array}{l}\text { Autor diskutuje o kritickom myslení v kontexte } \\
\text { dokonalosti myslenia. }\end{array}$ \\
\hline & Bailin (2002) & $\begin{array}{l}\text { premýšlanie o niečom určitom; kvalitné myslenie, ktoré } \\
\text { splńa zadané kritériá alebo štandardy primeranosti } \\
\text { a presnosti. }\end{array}$ \\
\hline \multirow[t]{3}{*}{$\begin{array}{l}\text { Kognitívno- } \\
\text { psychologický } \\
\text { prístup }\end{array}$} & Glaser (1941) & $\begin{array}{l}\text {... zahŕňa tri veci: 1) postoj - pripravenost' premýšlat', } \\
\text { 2) znalost' metód logického skúmania a uvažovania, } \\
\text { 3) určitá zručnost' pri uplatňovaní týchto metód. }\end{array}$ \\
\hline & $\begin{array}{l}\text { Watson } \\
\text { a Glaser (1990) }\end{array}$ & $\begin{array}{l}\text {... kombinácia schopností, znalostí a postojov, } \\
\text { umožňujúce jedincovi interpretovat', dedukovat', } \\
\text { rozpoznávat' predpoklady, hodnotit' argumenty a dospiet' } \\
\text { k záverom. }\end{array}$ \\
\hline & $\begin{array}{l}\text { Sternberg } \\
(1986)\end{array}$ & $\begin{array}{l}\text {... procesy, stratégie a zručnosti používané na riešenie } \\
\text { problémov, rozhodovanie a učenie nových konceptov. } \\
\text { Zručnosti - metakomponenty, komponenty výkonnosti } \\
\text { a komponenty na získavanie vedomostí. }\end{array}$ \\
\hline
\end{tabular}




\begin{tabular}{|c|c|c|}
\hline \multirow[t]{5}{*}{$\begin{array}{l}\text { Kognitívno- } \\
\text { psychologický } \\
\text { prístup }\end{array}$} & $\begin{array}{l}\text { Schafritz, } \\
\text { Koppe a Soper } \\
\text { (1988) }\end{array}$ & $\begin{array}{l}\text {... mentálny proces, ktorým jednotlivec získava a hodnotí } \\
\text { rôzne informácie, pričom je schopný vyvodzovat' logické } \\
\text { a objektívne úsudky. }\end{array}$ \\
\hline & Halpern (1998) & $\begin{array}{l}\text {... používanie tých kognitívnych zručností a stratégií, } \\
\text { ktoré zvyšujú pravdepodobnost' želaného výsledku. }\end{array}$ \\
\hline & $\begin{array}{l}\text { Williams et al. } \\
(2003)\end{array}$ & $\begin{array}{l}\text {... schopnost' vytvárat' predpoklady a prehodnocovat' } \\
\text { argumenty. }\end{array}$ \\
\hline & $\begin{array}{l}\text { Willingham } \\
(2007)\end{array}$ & $\begin{array}{l}\text {... nezaujaté uvažovanie, tvrdenie opierajúce sa o dôkazy } \\
\text { so schopnost'ou vyvodzovat' závery a riešit' problémy. }\end{array}$ \\
\hline & Ruisel (2008) & $\begin{array}{l}\text {... vedecké myslenie, formálna a neformálna logika, } \\
\text { pravdepodobnostné myslenie, hodnotenie kvality } \\
\text { informácií, generovanie a výber alternatív a cielov } \\
\text { a analyzovanie argumentov umožňujúcich vytvárat' } \\
\text { adekvátne závery. }\end{array}$ \\
\hline
\end{tabular}

Pedagogický, resp. Bloom et al. ... analýza, syntéza a hodnotenie - tri najvyššie úrovne vzdelávací prístup (1956) Kennedy et al. (1991) pôvodnej Bloomovej taxonómie podla niektorých autorov sčasti reprezentovali kritické myslenie.

Poprední odborníci sa koncom 20. storočia dohodli na kognitívnych oblastiach, ktoré by mali byt' zahrnuté do definície kritického myslenia. Lai (2011) ponúka prehlad relatívne akceptovaných komponentov kritického myslenia:

- analýza argumentov alebo dôkazov (Ennis, 1985; Facione, 1990; Halpern, 1998; Paul, 1992; Watson \& Glaser, 1990);

- hodnotenie (Case, 2005; Ennis, 1985; Facione, 1990; Lipman, 1988; Watson \& Glaser, 1990;);

- rozhodovanie alebo riešenie problémov (Ennis, 1985; Halpern, 1998; Willingham, 2007);

- určenie záverov pomocou induktívneho alebo deduktívneho uvažovania (Ennis, 1985; Facione, 1990; Paul, 1992; Watson \& Glaser, 1990; Willingham, 2007).

Zároveň boli identifikované aj d’alšie schopnosti relevantné ku kritickému mysleniu: pýtanie sa a odpovedanie na dotazy pre objasnenie (Ennis, 1985); identifikácia predpokladov (Ennis, 1985; Paul, 1992); interpretácia a vysvetlovanie (Facione, 1990); predvídanie (Tindal \& Nolet, 1995); vidiet' obe strany problému (Willingham, 2007) a iné.

Väčšina vedcov zastávala názor, že definícia kritického myslenia by mala obsahovat' aj dispozície (označované odborníkmi ako postoje a návyky mysle). Lai (2011) konštatuje, že odborníci najčastejšie uvádzajú tieto: otvorenost' (Bailin et al., 1999; Ennis, 1985; Facione, 1990; Halpern, 1998); ochota hladat' dôvody (Bailin et al., 1999; Ennis, 1985; Paul, 1992); túžba byt' dobre informovaný (Ennis, 1985; Facione, 1990); flexibilita (Facione, 1990; Halpern, 1998); rešpektovanie (Bailin et al., 1999; Facione, 1990) a iné.

Aj ked' v súčasnosti filozofické, kognitívno-psychologické a pedagogické diela poskytujú širokú škálu definícií kritického myslenia, pre nás je inšpiratívna definícia 
6 Ruisela (2008), podla ktorého ide o synonymum pre kvalitné alebo zrozumitel'né myslenie zahrňujúce tieto zložky:

1. motiváciu pre náročnost', ktorú vyvoláva kritické myslenie;

2. poznatky o schopnostiach kritického myslenia;

3. tréning štruktúry pre ul'ahčenie transferu medzi súvislost’ami;

4. metapoznávací monitoring.

K aplikácii týchto zložiek do vyučovacieho procesu je potrebná súhra afektívnej, kognitívnej aj konatívnej dimenzie. V afektívnej dimenzii je možné súhlasit' s komponentmi, ktoré vyššie uvádza Lai (2011). Ruisel (2008) však podáva ucelenejšie a komplexnejšie vysvetlenie, kde konštatuje, že kritické myslenie vyžaduje primeranú motiváciu k zvládnutiu náročného psychického úsilia vyplývajúceho z konkrétnych kognitívnych a afektívnych aktivít. Predpokladá sa antidogmatizmu a flexibilita, ochota hodnotit' informácie objektívne a pochopenie rozdielov medzi racionalizáciou a usudzovaním. Tieto nekognitívne aspekty kritického myslenia predpokladajú schopnost' a motiváciu posudzovat' problém z mnohorakých perspektív a tolerovat' nejasnost' a neurčitost'.

V kognitívnej dimenzii uprednostňujeme komponenty kritického myslenia podla Faciona (1990): 1) interpretácia (kategorizácia, pochopenie dôležitosti, objasnenie významu); 2) analýza (skúmanie myšlienok, identifikácia a analýza argumentov); 3) hodnotenie (posúdenie tvrdení a argumentov); 4) inferencia (usudzovanie, spochybňovanie dôkazov, hladanie alternatív, vyvodzovanie záverov); 5) explanácia (predstavenie záverov, odôvodnenie postupov a prezentácia záverov); 6) autoregulácia (sebahodnotenie a sebakontrola). Z hladiska rozvoja kritického myslenia edukantov v praxi sa nám tento model osvedčil najlepšie, pretože pomáha edukantovi prejst' celým procesom kritického myslenia od kontaktu s informáciou, schopnost'ou s ňou pracovat' $v$ širších súvislostiach, dospiet' k rozhodnutiu s odvolaním na relevantný argument (ako po formálnej, tak aj po obsahovej stránke) až po autoregulatívnu zložku.

Aby učitel' lahšie zabezpečil transfer medzi súvislost’ami a metapoznávacím monitoringom, vyžaduje sa správna aplikácia rôznych metód a foriem podporujúcich rozvoj kritického myslenia. Ruisel (2008) konštatuje, že ak sa kritické myslenie nevhodne uplatňuje v nových súvislostiach, nie je vždy úspešné. Preto sa obvykle vyžadujú stratégie, ktoré tento proces ulahčujú (aplikácia príkladov a výber poznatkov, ktoré môžu pôsobit' ako vybavovací klúč). Usudzovanie, riešenie problému a učenie sa závisia od kapacity kódovat' a manipulovat' s príbuznými poznatkami. Cielom štruktúrneho tréningu je naučit' jednotlivca, aby si uvedomil, kedy môže platne využit' svoje schopnosti. Výkonnou a regulačnou funkciou kritického myslenia ja metapoznávanie. Je založené na hodnotení vlastných poznávacích schopností a ich využití pri vyvodzovaní záverov o úrovni vlastného myslenia a učenia sa. Aby sme $\mathrm{k}$ tomu dospeli ako jedinci, potrebujeme učebné prostredie s novou paradigmou prístupu ku kultivácii osobnosti, na ktorú upozorňuje najnovšia štúdia prof. Zelinu (2017). Kritické myslenie je potrebné vnímat' komplexnejšie a nezaobíde sa bez týchto komponentov: 
- autoregulácia - prelomovou prácou v tejto oblasti podla Zelinu (2016) je Boekaerts, Pintrich, \& Zeindner, 2000; Boekaerts, 2005; zároveň odporúčame poznatky Zelinu (2017);

- metakognícia - premýšlanie o vlastnom myslení (Cross \& Paris 1988; Čavojová, 2016; Facione, 1990; Kuhn, 1991; Martinez, 2006 a i.);

- tvorivost' - vyžaduje schopnost' kriticky hodnotit' intelektuálne produkty, rovnako sa vyžaduje otvorenost' a flexibilita, ktoré sú považované za základné charakteristiky tvorivého myslenia (Bailin, 2002; Bonk \& Smith, 1998; Ennis, 1985; Paul \& Elder, 2006; Thayer-Bacon, 2000; Zelina, 2008, 2016);

- mimokognitívne faktory: motivácia - motivovaný človek má väčšiu pravdepodobnost' vytrvat' v situáciách, ktoré si vyžadujú kritické uvažovanie (Bean, 1996; Dewey, 1916; Facione, 1990; Halpern, 1998; Novack, 1960 a i.); spolupráca korene nachádzame v Piagetovskom prekonaní kognitívneho konfliktu (Piaget \& Inhelderová, 1970) a Vygotského zóny najbližšieho vývoja (Vygotskij, 1970). Tieto poňatia zdôrazňujú význam sociálnych interakcií pre podporu kognitívneho rozvoja (Abram et al., 2008; Bailin et al., 1999; Dillenbourg et al., 1996; Knapík, 2014, 2015, 2016; Thayer-Bacon, 2000;) a pod.

\section{Východiská formulácie vedeckej otázky}

Kritické myslenie sa $v$ historikom kontexte objavuje $v$ rôznych teóriách viac ako 2500 rokov. Aj ked' práce známych filozofov a psychológov sú dostupné, stále disponujeme minimom poznatkov o kritickom myslení v podmienkach Slovenska na rozdiel od zahraničia, kde problematika je predmetom vedeckého bádania už niekol'ko desiatok rokov. Efektivitu podporujúcu kognitívne schopnosti a postoje človeka spojené s myslením skúmali Ennis (napr. 1985); Schievella (1968); Gardner (1983); Marzano (1997 a i.); Scriven (1985); Sternberg (1986 a i.); Paul (1987); Facione (1990); Schaffer (1995) a i. V 80. rokoch 20. storočia bol v USA vel'ký záujem o ludí so schopnost'ou kriticky uvažovat'. V rôznych návrhoch a politických usmerneniach USA bola vyslovená požiadavka, že demokratická spoločnost' potrebuje vychovat' kriticky mysliacich luudí (Glaser, 1985).

Potrebu kritického myslenia dokazujú viaceré fakty. Prvé priečky v čitatel'skej gramotnosti zaznamenávajú krajiny (Šanghaj-Čína, Singapour, Taiwan, Kórea, Fínsko...), kde kritické myslenie a kreativita prostredníctvom motivácie a aktívneho zapojenia edukanta je jeden z najdôležitejších prvkov úspešného vzdelávacieho systému (Bagalová, Bizíková, \& Fatulová, 2014). Spomenieme aj merné prostriedky v danej oblasti, ako napr. California Critical Thinking Skills Test (Facione, 1990), Cornell Critical Thinking Test (Ennis, Millman, \& Tomko, 1985; Ennis \& Millman, 2005), Lawson's Psychological Critical Thinking Exam (Lawson, 1999), The Halpern Critical Thinking Assessment (Halpern, 2012); Critical Thinking Basic Concepts and Understandings Online Test (Elder, Paul, \& Cosgrovem, 2013) a i. Za dôležité považujeme aj efektívne zahraničné programy na podporu rozvoja kritického myslenia, 
8 napr. špecifický program STELLA - pre vyučovanie dejepisu a chémie; SPELT - pre vyučovanie matematiky, jazyka, vied o spoločnosti alebo ucelený program CORT zostavený de Bonom (Gavora, 1995); programy filozofického myslenia Lipmana; Projekt urýchlenia rozumového vývoja prostredníctvom výučby prírodných vied (CASE Cognitive Acceleration through Science Education); tréningový program Dimenzií učenia sa či Programy inštrumentálneho obohacovania vytvorené Feuersteinom a jeho spolupracovníkmi (cit. podla Fisher, 1997; Adey \& Shayer, 1994; Feuerstein et al., 1996; Marzano et al., 1997) alebo model rozvoja kognitívnych komponentov kritického myslenia (Facione, 1990). Zaujímavé sú aj výsledky analýzy zahraničných empirických výskumov (Kosturková, 2016).

Problematika kritického myslenia sa zvlášt' zdôrazňuje $v$ rámci vysokoškolského vzdelávania a procese europeizácie, ktorý začína Sorbonskou deklaráciou v roku 1998 o harmonizácii Európskeho vysokoškolského systému (ENQA, 2009)³. Vetráková (2014) konštatuje, že dosiahnutie porovnatel'nej úrovne vo vzdelávaní v regionálnom, národnom a európskom priestore vyvoláva potrebu prijat' všeobecne platné štandardy vysokoškolského vzdelávania. Oficiálne boli prijaté prostredníctvom rady odborníkov Joint Quality Initiative (Iniciatíva spoločnej kvality; JQI, 2004) v Dubline 2001 (ENQA, 2009). Vyšpecifikovali sa charakteristiky úspešných absolventov jednotlivých stupňov vzdelávania v týchto aspektoch (nazývané Dublinské deskriptory): získané vedomosti a porozumenie, uplatňovanie vedomostí a porozumenie, schopnost' formulovat' závery (úsudok), schopnost' komunikovat' vedomosti a porozumenie, schopnost' d'alšieho vzdelávania. Dôraz je kladený na rozvoj tzv. prenositel'ných zručností (Lesáková, 2009). Medzi ne patria predovšetkým komponenty kritického myslenia.

Sprievodné javy spojené s informačnou explóziou, globalizáciou a postmodernou spoločnost'ou priam žiadajú absolventov daných stupňov vzdelávania s rozvinutým kritickým myslením na požadovanej úrovni. Svetové ekonomické fórum (World Economic Forum; d'alej WEF) v Davose v roku 2015 definovalo 6 najdôležitejších oblastí človeka potrebných pre budúcnost': schopnost' komplexne riešit' problémy, kritické myslenie, tvorivé riešenie problémov, ludský manažment, koordinácia s ostatnými a emocionálna inteligencia (WEF, 2017). Kritické myslenie sa objavuje hned' na druhom mieste najpožadovanejších budúcich kvalít človeka. Odborníci si už dlhšiu dobu uvedomujú jeho potrebu. Zároveň boli definované stabilné zručnosti pre budúcnost', ktoré sú uvedené $v$ tabul'ke 2 . Z nich prevažná väčšina tvorí komponenty súvisiace s kritickým uvažovaním.

3 Harmonogram bolonského procesu: Sorbonská deklarácia (1998); Bolonská deklarácia (1999); Pražské komuniké (2001); Berlínske komuniké (2003); Bergenský summit (2005); Londýnske komuniké (2007); Leuvenské komuniké (2009); Budapešt' a Viedeň (2011); Bukurešt' (2012); Jerevan (2015). 
Tabul'ka 2 Súbor schopností potrebných vo všetkých pracovných obalstiach

\begin{tabular}{|c|c|c|c|}
\hline $\begin{array}{l}\text { Schopnosti } \\
\text { (Abilities) }\end{array}$ & $\begin{array}{l}\text { Základné zručnosti } \\
\text { (Basic Skills) }\end{array}$ & $\begin{array}{l}\text { Ďalšie zručnosti } \\
\text { (Cross functional Skil }\end{array}$ & \\
\hline $\begin{array}{l}\text { Kognitívne schopnosti } \\
\text { Kognitívna flexibilita } \\
\text { Kreativita } \\
\text { Logické zdôvodnenie } \\
\text { Citlivost' problému } \\
\text { Matematická úvaha } \\
\text { Vizualizácia } \\
\text { Fyzické schopnosti } \\
\text { Fyzická sila } \\
\text { Ručná zručnost' } \\
\text { a presnost' }\end{array}$ & $\begin{array}{l}\text { Zručnosti obsahu } \\
\text { Aktívne učenie } \\
\text { Ústne vyjadrenie } \\
\text { Čítanie } \\
\text { s porozumením } \\
\text { Písomné vyjadrenie } \\
\text { IKT gramotnost' } \\
\text { Procesné zručnosti } \\
\text { Aktívne počúvanie } \\
\text { Kritické myslenie } \\
\text { Monitorovanie seba } \\
\text { a iných }\end{array}$ & $\begin{array}{l}\text { Sociálne zručnosti } \\
\text { Koordinácia } \\
\text { s ostatnými } \\
\text { Emočná inteligencia } \\
\text { Schopnost' jednat' } \\
\text { Presvedčenie } \\
\text { Orientácia na služby } \\
\text { Školenie a výučba } \\
\text { ostatných } \\
\text { Systémové zručnosti } \\
\text { Rozsudok } \\
\text { a rozhodovanie } \\
\text { Analýza systémov } \\
\text { Zručnosti riešenia } \\
\text { problémov } \\
\text { Komplexné riešenie } \\
\text { problémov }\end{array}$ & $\begin{array}{l}\text { Zručnosti riadenia } \\
\text { zdrojov } \\
\text { Riadenie finančných } \\
\text { zdrojov } \\
\text { Riadenie spoločnost } \\
\text { Materiálové zdroje } \\
\text { Manažment l'udí } \\
\text { Manažment času }\end{array}$ \\
\hline
\end{tabular}

Zdroj: WEF (2017, p. 20)

Je zrejmé, že od absolventov daného stupňa vzdelávania sa bude vyžadovat' aplikácia rozvinutých spôsobilostí v d’alšom vzdelávaní a následne v praxi. Celosvetové trendy sa postupne po roku 1989 prenášajú aj do slovenského školstva. Ešte konkrétnejšie $v$ rámci transformačných zmien a schválením školského zákona v roku 2008 sa oficiálne vytvoril priestor aj pre rozvoj kritického myslenia. Z toho vyplýva formulovaný problém, ako sa premieta problematika kritického myslenia do vedeckej činnosti odborníkov na Slovensku registrovanej v časopiseckej literatúre za obdobie rokov 2008-2017.

\section{Metodológia prehl'adovej štúdie}

Metodológia šetrenia bola postavená na systematickom mapovaní (systematic map; Mareš, 2013), ktorého zámerom bol prehl'ad výsledkov príspevkov v oblasti kritického myslenia.

Ciel'om prehladovej štúdie je integrovat' doterajšie poznatky a analyzovat' stav bádania v kritickom myslení na Slovensku za vybrané obdobie v domácej časopiseckej literatúre. V prehl'ade bol záujem sústredený na oblasti kritického myslenia súvisiace s edukačnou praxou: 
- zistit', kol'ko vedeckých a odborných článkov súvisiacich s kritickým myslením registrujeme v domácej časopiseckej literatúre za obdobie rokov 2008-2017,

- identifikovat' oblast' skúmania a charakter príspevkov,

- zistit', ktoré témy (resp. komponenty) sú predmetom záujmu zverejnených príspevkov,

- zistit', na ktoré cielové skupiny sú príspevky orientované,

- zhodnotit' celkový stav $v$ problematike $v$ kontexte vízií a reality.

Východiskom pre vymedzenie rozsahu rešerše bol samotný jav kritické myslenie. Určujúcim kritériom bolo klúčové slovo kritické myslenie. Základný súbor tvorili všetky výstupy ku klúčovému pojmu kritické myslenie a critical thinking v domácej časopiseckej literatúre v SR za roky 2008 až 2017 prostredníctvom rozšíreného vyhladávania v Centrálnom registri evidencie publikačnej činnosti (d'alej CREPČ). Predmetom vyhladávania boli kategórie ADD, ADN, ADF, BDD, BDN, BDF. Ked'že existujú v časopisoch aj príspevky autorov z mimouniverzitného prostredia, využili sme rozšírené vyhl'adávanie ku klúčovému pojmu pomocou portálu www.kis3g (kategória: časopisy). Zo zoznamu sa vyradili tie tituly, ktoré boli súčast’ou prvého vyhl'adávania pomocou CREPČ. Prvotnému vyhladávaniu zodpovedalo 137 príspevkov. Po preštudovaní titulov a abstraktov, kritickému čítaniu boli podrobené články, ktoré sa zdali relevantné vo vzt'ahu k skúmanej problematike. Štúdie redundantného charakteru boli vylúčené. Do prehl'adovej štúdie bolo nakoniec zaradených 72 príspevkov publikovaných v odborných a vedeckých časopisoch, štúdie evidované v profesijných databázach a príspevky vydané v populárno-náučných časopisoch, tie prešli procesom dôkladnej analýzy (vid'. tabul'ka 3).

Analytické kategórie boli stanovené prostredníctvom kódovacej tabul'ky podla Mareša (2013, s. 444), s doplnením vlastných kategórií pre potreby prehl'adu: 1) autor a rok vydania práce, 2) oblast' skúmania, 3) charakter príspevku, 4) výskumná otázka, 5) klúčové pojmy, 6) použitá metodológia, 7) hlavné zistenia a závery, 8) cielová skupina.

Najskôr sa analyzovalo 5 príspevkov s cielom tvorby vyššie uvedených analytických kategórií, nasledovala kontrola z pohl'adu nezávislého výskumníka s cielom overenia správnosti postupu. Procesom analýzy následne prešli všetky príspevky zaradené do výberového súboru $(n=72)$. Nezávislý výskumník po ukončení analýzy náhodne vybral 5 príspevkov a postúpil ich kontrole. Analýza prebiehala od mája 2017 do septembra 2017. Tabul'ka 3 predstavuje súpis časopiseckej literatúry analyzovaných príspevkov.

Doplňujúcou informáciou je obrázok 1 prezentujúci orientáciu príspevkov na cielové skupiny. Najväčší počet príspevkov bol venovaný sekundárnemu vzdelávaniu $(n=26 ; 36,11 \%)$ a terciárnemu vzdelávaniu $(n=16 ; 22,22 \%)$. Vo všeobecnej rovine sa vyskytlo 12 príspevkov (16,67\%), pri ktorých nebolo možné určit' bližšiu špecifikáciu cielovej skupiny. Predškolskú a elementárnu edukáciu reprezentovalo 10 príspevkov (13,90\%), učitel'om bolo venovaných 7 príspevkov $(9,72 \%)$ a jeden príspevok rodičom (približne $1,38 \%$ ). 
Tabul'ka 3 Súpis časopiseckej literatúry analyzovaných príspevkov

\section{Časopis}

Acta Humanica

Communication Today

Didaktika

Disputationes Scientificae Universitatis Catholicae in Ružomberok

Dobrá škola

Edukácia

Filozofia

Fyzikálne listy

Geografia Cassoviensis

Human Affairs

Journal of Language and Cultural Education

Manažment školy v praxi

Múzy v škole

Naša škola

Notes

Pán učitel'

Pedagogická revue

Pedagogické rozhlady

Pedagogika.sk

Predškolská výchova

Psychológia a patopsychológia diet'at'a

Quark

Rodina a škola

Romboid

Slavonic Pedagogical Studies Journal

Slovenčinár: časopis SAUS

Slovenská literatúra: revue pre literárnu vedu

Slovenský jazyk a literatúra v škole

Studia psychologica

Technika a vzdelávanie

Technológia vzdelávania

University review

Vychovávatel'
Početnost'

(n)

2

3

5

1

6

5

2

1

1

1

1

5

1

7

1

2

2

5

2

1

1

1

3

1

1

1

1

2

2

1

1

1

2 


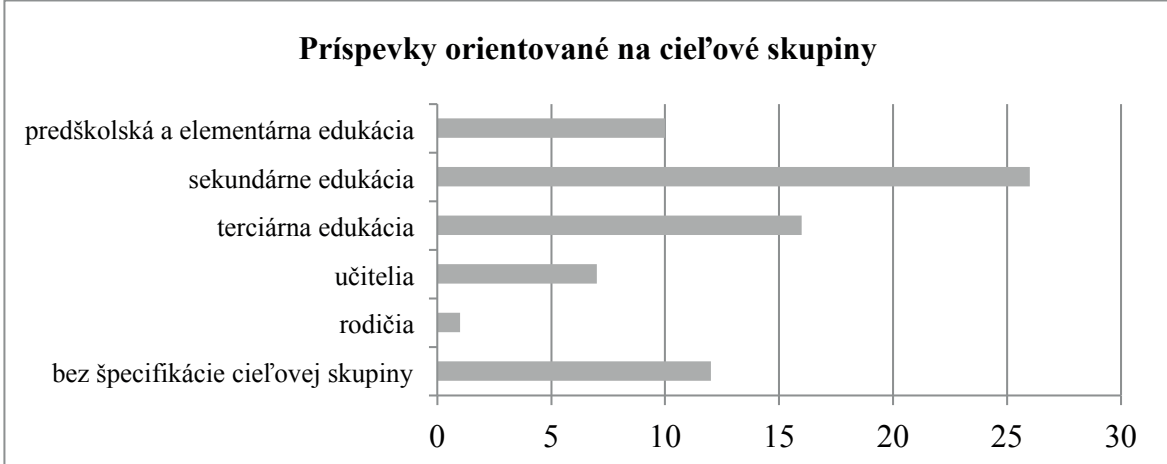

Obrázok 1 Frekvencia príspevkov vo vzt’ahu k identifikovaným skupinám

$\checkmark$ rámci interpretácie sme zvolili neutrálny výklad, kde boli interpretované jednotlivé príspevky tak, aby neskreslili názory výskumníkov. Základom bolo zachytit' vybrané aspekty skúmanej problematiky v kontexte transformačných zmien od oficiálneho zavedenia rozvoja kritického myslenia do edukačnej praxe na Slovensku.

\section{Výsledky a diskusia k problematike skúmania kritického myslenia na Slovensku}

Od oficiálneho zavedenia rozvoja kritického myslenia do Štátneho vzdelávacieho programu SR v roku 2008 ubehlo 10 rokov. Za toto obdobie (2008-2017) bolo v časopiseckej literatúre na Slovensku publikovaných niekol'ko desiatok príspevkov. Predmetom systematického mapovania bolo 72 príspevkov, ktorých obsahové zameranie súviselo s poznatkami o kritickom myslení širšie dotýkajúcich sa výchovy a vzdelávania (tabul'ka 3).

Z hladiska oblasti skúmania je možné príspevky rozdelit' do troch základných skupín: a) filozofické; b) psychologické; c) edukačno-vedné. Najpočetnejšie zastúpenie príspevkov bolo $v$ edukačno-vednej oblasti $(n=60 ; 83,33 \%)$. Vo filozofickej oblasti bolo identifikovaných 9 príspevkov (12,50 \%) a v psychologickej 3 príspevky $(4,17 \%)$. Vo vzt'ahu $k$ tomuto komponentu nachádzame vel'mi slabé zastúpenie príspevkov z filozofického a psychologického hladiska. Táto absencia híbkového skúmania etymológie a významu kritického myslenia spôsobuje značnú mystifikáciu a symplifikáciu problému aj v edukačno-vednej rovine. Kritické myslenie nie je skúmané komplexne a do híbky, a ako poznamenáva Zelina, pojem sa často používa ako klišé alebo ako módny pojem.

Charakter príspevkov bol rozdelený do štyroch oblastí. Dominanciu tvorili teoreticko-aplikačné ( $n=28 ; 38,89 \%$ ), s orientáciou na predčitatel'skú a čitatel'skú gramotnost' ( $n=7$; napr. Koníčková, 2010/2011; Ludvigová, 2012/2013; Sámelová, 2012/2013 atd'.) a na metodiky podpory rozvoja kritického myslenia $(n=21)$. Pria- 
mo o kritickom myslení pojednávajú len niektoré odborné články, napr. Ferencovej a Šut'ákovej (2011); Petláka (2012-2013; 2016a), Pavlíkovej (2013-2014), Kosturkovej (2012a, 2012b), Knapíka (2013b). Analýzou týchto článkov bolo zistené, že ide prevažne o čiastkové námety a metodické odporúčania, ako podporit’ rozvoj kritického myslenia v edukácii, príp. o úlohu kriticky mysliaceho učitel'a ako sprievodcu žiakov. Tieto príspevky sú v prevažnej miere zamerané na cielovú skupinu v predškolskej, elementárnej a sekundárnej edukácie ZŠ (ojedinele v stredných školách a v pregraduálnej príprave budúcich učitel'ov). Ďalšiu kategóriu zastupujú teoretické príspevky ( $n=20 ; 27,78 \%$ ). Medzi nimi sa objavujú práce s tematikou kritického myslenia všeobecne aj vo vzt’ahu k nástrahám dnešného sveta, internetu a pod. (napr. Kotrč, 2009; Plencner, 2014 a i.). Z analýzy vyplynulo, že iba 22,22 \% ( $n=16)$ tvoria empirické štúdie. Za podnetnú považujeme štúdiu napr. Čavojovej a Jurkoviča (2017), v ktorej autori skúmali kognitívnu reflexiu učitel'ov vo vzt’ahu ku kritickému mysleniu. Vel'ký význam pre edukačnú prax majú experimentálne štúdie (napr. Petranová, 2011). Celkovo boli identifikované 3 experimentálne štúdie. V časopiseckej literatúre sa objavili aj populárno-náučné príspevky $(n=8 ; 11,11 \%)$, ktorých úvaha smeruje prevažne k potrebe a deficite kritického myslenia $v$ školstve a v spoločnosti (napr. Gažovič, 2017).

Obsah jednotlivých príspevkov bol kategorizovaný do 9 oblastí. Frekvenciu tematiky vo vzt’ahu k oblasti kritického myslenia uvádza obrázok 2.

\section{Tematické zameranie príspevkov}

príspevky o deficite KM v edukácii a spoločnosti

diagnostika vybraných komponentov KM

vybrané aspekty KM z filozofického hl'adiska

rozvoj čitatel'skej gramotnosti s dôrazom na KM učitel' podporujúci učebné prostredie na rozvoj KM vybrané aspekty KM zo psychologického hl'adiska štúdie na rozvoj KM experimentálne štúdie

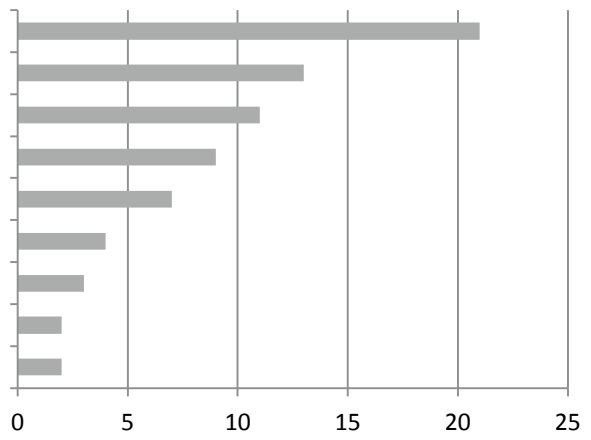

Obrázok 2 Frekvencia tematiky vo vzt’ahu k problematike kritického myslenia (KM)

Najpočetnejšie zastúpenie príspevkov bolo orientované na metodiky rozvoja kritického myslenia ( $n=21 ; 29,17 \%$ ). Túto skupinu tvoria prevažne články zaoberajúce sa metodikou, ako uplatnit' vybrané stratégie a metódy v edukácii vo vzt’ahu k rozvoju kritického myslenia žiakov. Z hl'adiska tematického zamerania druhú najpočetnejšiu skupiny tvorili príspevky o deficite a potrebe kritického myslenia $v$ školstve a spoločnosti ( $n=13 ; 18,06 \%$ ). Ďalšie skupiny boli: diagnostika vybraných kompo- 
14 nentov kritického myslenia ( $n=11 ; 15,28 \%)$, filozofické články ( $n=9 ; 12,50 \%)$, rozvoj čitatel'skej gramotnosti s dôrazom na kritické myslenie $(n=7 ; 9,72 \%)$, učebné prostredie $(n=4 ; 5,56 \%)$, psychologické štúdie a články $(n=3 ; 4,16 \%)$. Najmenšie zastúpenie sme evidovali $v$ dvoch oblastiach - štúdie reflektujúce rozvoj kritického myslenia ( $n=3$; približne 4,16 \%) a tri experimentálne štúdie (približne 4,16\%).

Z tematického zamerania zvlášt' za dôležité považujeme empirické štúdie, ktorých za sledované obdobie bolo len $n=16$ (približne $22,22 \%$ ). Tento počet je zanedbatel'ný oproti výsledkom zo zahraničia, o ktorých bolo pojednávané v teoretických východiskách. Dôležitým komponentom pre naše školstvo je oblast' diagnostiky vybraných komponentov kritického myslenia. Tejto kategórii zodpovedalo 11 empirických štúdií. Medzi nimi sa nachádzajú štúdie, ktorých závery smerujú k zisteniu, že 16-roční gymnazisti $(N=365)$ mali problém robit' úsudky, teda logické závery, ku ktorým mali dospiet' na základe pozorovaných alebo predpokladaných faktov; mali problém hodnotit' argumenty, ktoré sú na daný problém podstatné alebo nepodstatné a pod. (Kosturková, 2013a). Ide o súbor respondentov východoslovenskej lokality. Žial' musíme konštatovat', že učitelia majú v tejto oblasti tiež vel'ké nedostatky (Kosturková, 2013b). Nemôžeme očakávat', že edukanti budú mat' rozvinuté schopnosti kritického myslenia, ked' učitelia ich nemajú tiež. Z výsledkov d'alšieho prieskumu učitel'ov stredných škôl Prešovského kraja vyplynulo, že najčastejšími termínmi, ktorými zadávajú úlohy žiakom sú: vypište, charakterizujte, vyhladajte, definujte. Tieto úlohy sú zamerané na nižšie kognitívne procesy. Úlohy, ktorými učitel' od žiakov očakáva vyššie kognitívne schopnosti ako pozorujte a posúd'te, vytvorte a zargumentujte sa vyskytujú v praxi respondentov len ojedinele. Podobné výsledky, ale so zámerom na mediálnu výchovu, nachádzame v štúdiách Petranovej (2011, 2013). V jednej z nich autorka predstavuje výsledky experimentálneho zásahu u žiakov gymnaziálneho typu štúdia, kde výberový súbor tvorili dve experimentálne triedy a dve kontrolné. Výsledky výskumu ukázali, že žiaci absolvujúci predmet mediálna výchova mali v priemere rovnakú schopnost’ kritického myslenia ako žiaci, ktorí daný predmet neabsolvovali. $V$ kontexte týchto analýz sú relevantné zistenia týkajúce sa možností či bariér rozvoja kritického myslenia žiakov zo strany pedagógov. U tejto kategórie zvlášt' apelujeme na posilnenie pedagogického myslenia prostredníctvom programov kontinuálneho vzdelávania so zameraním na kurz formálnej a neformálnej logiky. Kritické myslenie sa zaujíma aj o tie učebné stratégie, ktoré kvalitatívne zlepšia edukantove postupy pri učení (zapamätanie, uchovávanie v pamäti a vybavovanie). Ide o grafické organizátory. Význam využívania mentálnej reprezentácie učiva prostredníctvom pojmového mapovania, ako možnosti rozvoja vyšších kognitívnych funkcií, empiricky skúmali Petrová a Kozárová (2017). Celkovo hodnotíme, že na základe uvedených štúdií nemožno komplexne identifikovat' bariéry a možnosti rozvoja kritického myslenia žiakov, ktoré by umožňovali kreovat' ucelenú koncepciu rozvoja tejto spôsobilosti v školách. Paradoxom je, že rozvoj kritického myslenia je jednou z cielových požiadaviek Štátneho vzdelávacieho programu SR. Bolo by na mieste položit' si otázku, čo viedlo $\mathrm{k}$ jeho zakomponovaniu do oficiálneho kurikulárneho dokumentu a aké miesto by mala mat' táto problematika v edukačnej praxi. 
Z oblasti vysokoškolského vzdelávania intenzívnejší trend formovania a rozvíjania kritického myslenia (prevažne štúdie v recenzovaných zborníkoch, ojedinele monotematické práce) registrujeme u viacerých autorov až v posledných rokoch: napr. Petrasová (2000; 2008); Ruisel (2008); Ruisel a Ruiselová (2011); Knapík (2013a; 2013b); Smetanová, Drbalová, \& Vitáková (2015); Smetanová, Flamíková, \& Hrašová (2015); Velmovská (2014; 2015); Petríková (2015); Velmovská a Bartošovič (2016); Čavojová (2016); Ištvan (2016) a pod. V slovenskej časopiseckej literatúre však existuje vel'mi málo empirických štúdií zaoberajúcich sa danou témou. Tie, ktoré sú predmetom tejto prehladovej štúdie, väčšinou pochádzajú od autorov Katedry pedagogiky FHPV v Prešove. Závery štúdií poukazujú na neuspokojivý stav kritického myslenia vysokoškolákov viacerých skupín na Slovensku, ktorý je hlboko pod priemerom v európskom kontexte. Zároveň z tohto pracoviska vychádzajú viaceré podnety vedúce k podpore rozvoja kritického myslenia študentov učitel'stva prostredníctvom ich didaktickej prípravy (Ferencová, 2017; Kosturková, 2017a, b; Šutáková \& Ferencová, 2017). Dovolíme si zhodnotit', že v odbornej komunite sa venuje málo pozornosti komplexnému skúmaniu kritického myslenia budúcich učitel'ov. V domácich časopisoch sme našli jediný pokus o overenie programu rozvoja kritického myslenia študentov učitel'stva. Štúdia predstavuje dôležitý prvok rozvoja danej spôsobilosti, a to schopnost' klást' otázky. Experiment bol aplikovaný vo vybraných študijných predmetoch počas 13 týždňov v troch vybraných skupinách (kontrolná skupina - n = 21; experimentálna skupina $1-n=21$; experimentálna skupina $2-n=20$ ). Hlavným zistením bolo, že aktivizovaním študenta a systematickým pôsobením je možné rozvíjat' techniku kladenia otázok (Kosturková, 2017c). Nápomocnými boli viaceré modely rozvoja kritického myslenia napr. Facione (1990), Marzano et al. (1997), Paul a Elder (1992, 2003) a i. V zimnom semestri akademického roka 2016/2017 prebehlo experimentálne overenie študentov učitel'stva v schopnosti argumentovat'. Predbežné výsledky sa orientujú na odporúčania vedúce k posilneniu argumentácie, tvorbe relevantných argumentačných línií, aplikácií cvičení na odhalenie manipulácie, chyby v logike a pod. (ešte nepublikovaný zdroj). Z vyššie naznačených analýz vyplýva potreba základov modernej logiky už v základnej a strednej škole. Štúdia Gavoru a Matúšovej (2010) je orientovaná na zistenia o úrovni študentov učitel'stva $v$ čitatel'skej gramotnosti ako komponentu úzko súvisiaceho s kritickým myslením. Autori zistili, že študentom učitel'stva robí najväčší problém kriticky čítat', argumentovat' a hodnotit' vlastné názory. Diskusiu podporíme zdrojmi z mimočasopiseckej literatúry. Dôkazom o nedostatočnej schopnosti vysokoškolákov kriticky mysliet' sú výsledky projektu Assessment of Higher Education Learning Outcomes (d'alej AHELO) ${ }^{4}$, ktorý bol spustený v roku 2010. Nedelová (2013) konštatovala nepriaznivé výsledky vysokoškolákov v zručnostiach: analýza a hodnotenie informácií, riešenie problému a efektívnost' písania zameraná na kritické myslenie. Mertová (2015, s. 229) na túto skutočnost' reaguje prostredníctvom metaforického modelovania reality. Hladá spô-

4 Projekt AHELO je zameraný na hodnotenie kvality vysokoškolského vzdelávania. Jeho ciel’om je zistit', či je možné hodnotit' a porovnávat' výsledky vysokoškolského vzdelávania medzi jednotlivými krajinami s rôznou kultúrou a jazykmi (Pasternáková, 2014). 
16 sob, ktorým je možné prirodzene pristupovat' k racionálnemu zachyteniu každodennej objektívnej reality, hodnoteniu a ponímaniu sveta ako takého. V pregraduálnej príprave na učitel'ské povolanie sa venuje málo pozornosti vzájomnej podmienenosti globálnych a regionálnych vzdelávacích systémov. Dnes o vzdelávaní v tomto kontexte vieme viac, ale aj tak školy nemeníme, a v praxi často konáme proti empirickým poznatkom, lebo sme rigorózne ukotvení v starých modeloch (Rovňanová, 2015). Predpokladáme, že budúcim učitel'om bude chýbat' teoretický aj praktický rozmer tejto problematiky. Ťažko môžeme očakávat', že absolventi učitel'ských študijných programov budú vediet' rozvíjat' kritické myslenie u svojich žiakov, aj ked' táto požiadavka je dlhodobo deklarovaná ako národnými dokumentmi (napr. ŠVP SR), tak aj medzinárodnými (WEF, 2017; Zelina, 2016). V tomto smere apelujeme na zásadnú zmenu postoja ako študentov učitel'stva, tak aj učitel'ov z praxe (Petlák, 2016b). S tým úzko súvisí kognitívna reflexia a autoregulácia. Na nedostatočnú úroveň kognitívnej reflexie (súvisiacej s kritickým myslením) najmä začínajúcich učitelov poukazujú v štúdii Čavojová a Jurkovič (2017). Za podnetnú prácu v oblasti autoregulácie (jedného zo základných komponentov kritického myslenia) považujeme štúdiu Zelinu (2017). Na tieto trendy budúcnosti odporúčame pripravit' hlavne študentov učitel'stva, aby vedeli naučit' procesy usudzovania svojich edukantov a podporili schopnost' konštruktívnejšie riešit' problémy.

Najmenej pozornosti v rámci vysokoškolského štúdia je venovanej skúmaniu kritického myslenia v prostredí študentov 3. stupňa. Lesáková (2013) a Kosová (2017) pri tejto skupine upozorňujú na potrebu rozvoja prenositel'ných generických zručností (medzi nimi aj kritické myslenie). Autorky, vychádzajúc zo Salzburských princípov, ich považujú za základnú súčast' doktorandského vzdelávania, ktorý má smerovat' k pokroku vedomostí prostredníctvom originálneho výskumu. Sme názoru, že doktorand by mal byt' schopný využivat' híbkový a analytický prístup k informáciám, mal by byt' schopný preukázat' híbkové poznatky, vyjadrit' svoj názor s podporou relevantného argumentu a pod. $V$ skúmaní kritického myslenia tejto skupiny respondentov zaznamenávame asi najväčší deficit. V slovenskej časopiseckej literatúre sme nenašli zdroj, ktorý by bol relevantný vo vzt’ahu k skúmanej nosnej premennej. ${ }^{5}$

\section{Záver}

Kurikulárna reforma $v$ SR oficiálne vytvorila priestor pre rozvoj jednej z najpožadovanejších kvalít budúcnosti, a to rozvoj kritického myslenia. Prehl'adová štúdia odráža diametrálne odlišný záujem odbornej verejnosti o riešenie problematiky v zahraničí a na Slovensku. Prioritne zachycuje vývoj bádania kritického myslenia

5 Poznámka autoriek: Jediný zdroj prezentujúci aktuálny stav kritického myslenia doktorandov denných študijných programov bol v zborníku vedeckých štúdií publikovaný Katedrou psychológie na Filozofickej fakulte Prešovskej univerzity v Prešove. Závery štúdie poukazujú na neuspokojivé výsledky v kritickom uvažovaní doktorandov. Aj tieto výsledky prispievajú $\mathrm{k}$ faktu, že vo všetkých stupňoch vzdelávania v SR absentuje systematický rozvoj schopnosti kriticky mysliet'. 
v domácej časopiseckej literatúre od oficiálneho zavedenia vízie rozvoja kritického myslenia do národných dokumentov, t. j. v rokoch 2008-2017. Analýza 72 príspevkov, ktoré prešli procesom triedenia, bola sústredená na zistenie reálneho stavu publikovaných príspevkov (vedeckých, odborných a pod.), identifikovanie oblastí a charakteru príspevkov, tematického zamerania príspevkov, diagnostiku stavu kritického myslenia edukantov a edukátorov, identifikáciu bariér a možností rozvoja spôsobilosti, ako aj experimentálne overenie efektívnosti stratégií rozvoja kritického myslenia $v$ školskej edukácii.

V intenciách rozvoja klúčových kompetencií pre celoživotné vzdelávanie človeka $\checkmark$ 21. storočí sa pri dosahovaní hlavných cielov vzdelávania (vrátane všetkých stupňov) predpokladalo používanie tých učebných postupov, ktoré podporia rozvoj danej spôsobilosti. Žial', ani určenie rozvoja kritického myslenia, ako jednej z cielových požiadaviek Štátneho vzdelávacieho programu, neprinieslo jej naplnenie v praxi slovenských škôl. Analýzou príspevkov bolo zistené, že odborná verejnost' venuje vel'mi málo pozornosti problematike kritického myslenia $v$ časopiseckej literatúre:

- dominujú predovšetkým teoretické a aplikačné odborné články s orientáciou na predčitatel'skú a čitatel'skú gramotnost', príspevky reflektujúce potrebu kritického myslenia $v$ edukácii a $v$ spoločnosti,

- $\vee$ prevažnej väčšine sú príspevky orientované na cielovú skupinu pre sekundárne vzdelávanie,

- z hladiska tematického zamerania príspevkov dominujú metodiky rozvoja kritického myslenia,

- v empirickej oblasti bolo v časopiseckej literatúre identifikovaných 16 vedeckých štúdií venovaných kritickému mysleniu, z toho jeden experimentálny výskum vo vysokoškolskej výučbe študentov učitel'stva a dva u žiakov gymnázií,

- z hladiska oblasti výskumu absentujú filozofické a psychologické štúdie.

Domnievame sa, že tento fakt sa odráža aj v skutočnosti, že formálne sa síce vytvorili podmienky pre realizáciu reformy aj v oblasti rozvoja kritického myslenia, no $v$ skutočnosti chýbala obsahová reforma, d’alšie podmienky ako podporné mechanizmy zavádzania zmien zo strany učitel'ov, vrátane nedostatočnej pregraduálnej prípravy a efektívneho systému kontinuálneho vzdelávania.

$Z$ analýzy vyplynulo, že rozvíjanie kritického myslenia je $v$ slovenských školách doposial' stále na neuspokojivej úrovni. Edukačná prax a výsledky edukantov slovenských škôl vypovedajú o dominujúcej orientácii školského vzdelávania na množstvo zapamätaných informácií. Vyššie kognitívne procesy ako súčast' kritického myslenia nie sú cielene rozvíjané a ani náležite oceňované. V praxi učitelov prevládajú metódy a postupy založené na prevažnej aktivite učitel'a, jeho monológu. $V$ niektorých prípadoch sa dokonca redukujú len na diktovanie poznámok, ktoré je z pozície učitel'ov vnímané v súvislosti s neexistenciou kvalitných učebníc ako nevyhnutnost'. Celý problém v súvislosti s nelichotivým stavom a vývojom kritického myslenia slovenských žiakov je však potrebné vidiet' komplexnejšie. Jeho korene siahajú určite hlbšie do minulosti a súvisia s dlhoročnými centralizačnými tendenciami vo vzdelávacej politike i tradíciami informatívneho učenia (Kosová \& Porubský, 2011a, b). 
18 V súčasnosti niet pochýb o tom, že nelichotivý vývoj a súčasný stav kritického myslenia slovenských žiakov súvisí so spôsobom, akým boli realizované reformné zmeny po roku 1989. S odstupom takmer tridsiatich rokov je možné konštatovat', že v oblasti orientácie vzdelávania na rozvíjanie kritického myslenia, podobne ako v iných cielových oblastiach edukácie, neboli naplnené deklarované vízie a očakávania. Uvedomenie si a pomenovanie bariér jeho rozvoja je dôležitým východiskom pozitívnej zmeny. Odborníci (Kosová \& Porubský, 2011a, b; Kosová, 2017; Porubský, 2017) k tým najvýznamnejším radia tieto:

- nízka miera motivácie učitel'ov, rezignácia, neochota k zmene, zvádzaniu inovácií;

- nízky status pedagogickej profesie na jednej strane v protiklade k vysokým očakávaniam zo strany štátu, rodičov a vysokým nárokom na profesiu učitel'a, vrátane administratívnej zát’aže;

- reálna absencia obsahovej reformy, kvalitných kurikulárnych dokumentov a učebníc;

- charakter pregraduálnej prípravy i systém kontinuálneho vzdelávania učitelov, ktorý zatial' nezodpovedá výchove kriticky mysliaceho a kritické myslenie rozvíjajúceho učitel'a.

Vychádzajúc $z$ vyššie uvedeného je $v$ d’alšom období potrebné:

- zvýšit' mieru angažovanosti učitel'ov pri hladaní a overovaní metód a postupov vedúcich k rozvíjaniu kritického myslenia žiakov, podporovat' ich entuziazmus pri zavádzaní zmien do vyučovacieho procesu systematickým monitorovaním ich práce a odmeňovaním iniciatívnych učitelov (Petrasová, 2008; Čavojová \& Jurkovič, 2017; Kosová, 2017; Zelina, 2017);

- pregraduálnu prípravu učitelov orientovat' viac na problematiku rozvíjania klúčových kompetencií, vrátane kritického myslenia ako jednej z najdôležitejších spôsobilostí potrebnej pre život v súčasnej spoločnosti, a to cielenou edukáciou $v$ tomto smere, ale aj vlastnou edukačnou praxou vysokoškolských učitel'ov (Velmovská \& Bartošovič, 2016; Kosturková, 2016; Kosová, 2017; Zelina, 2017);

- podporovat' zmeny $v$ systéme kontinuálneho vzdelávania, ktoré by nemalo byt' založené len na zbieraní kreditov absolvovaním vzdelávacích programov realizovaných externými inštitúciami, ale systematickým spoločným vzdelávaním učitelov v prostredí vlastnej školy, spoločným zdielaním pozitívnych skúseností pri rozvíjaní kritického myslenia žiakov (Šnídlová, 2010; Kubalíková, 2015; Pavlov \& Krystoň, 2017; Šutáková, 2017);

- posilnit' tzv. kolaboratívnu kultúru škôl cieleným vzdelávaním školského manažmentu schopného podporovat' tímovú spoluprácu, inovácie a pozitívne postoje pedagogických zamestnancov k zmenám a k hladaniu efektívnych ciest rozvíjania klúčových oblastí vzdelávania, vrátane orientácie na rozvijanie kritického myslenia a d’alších klúčových spôsobilostí žiakov (Kubalíková, 2015; Šut’áková \& Ferencová, 2017). 
Z prehl'adovej štúdie vyplýva fakt, že problematika stavu, bariér i možností rozvíjania kritického myslenia v procese školskej edukácie nie je doposial' systematicky a komplexne uchopená, a dostatočne podporená empirickým skúmaním. Absentujú experimentálne programy rozvoja danej spôsobilosti.

Problém vidíme $v$ tom, že chýba systematická podpora zavádzania a experimentálneho overovania rozvoja kritického myslenia zo strany štátu, $v$ národných dokumentoch nenachádzame konkrétne vypracovanú stratégiu rozvoja tejto spôsobilosti a nie je jasne definované, akým spôsobom je možné zhodnotit' pokrok v tejto oblasti.

Za najdôležitejšie považujeme, aby sa vzdelávanie stalo skutočnou, nie len formálnou prioritou štátnej politiky.

\section{Pod'akovanie}

Štúdia $v$ tejto podobe je výsledkom zapracovania konštruktívnych pripomienok do textu od oboch editorov tohto čísla časopisu, ako aj recenzentov. Touto cestou autorky d'akujú všetkým za podnetné pripomienky, ktoré prispeli k obsahovo vyššej kvalitatívnej úrovni štúdie.

\section{Literatúra}

Abram, P. C., Bernard, R. M., Borokhovski, E., Wade, A., Surkes, M. A., Tamim, R., \& Zhang, D. (2008). Instructional interventions affecting critical thinking skills and dispositions: A stage 1 meta-analysis. Review of Educational Research, 78(4), 1102-1134.

Adey, P., \& Shayer, M. (1994). Really raising standards: cognitive intervention and academic achievement. London: Routledge.

Bailin, S. R., Case, R., Coombs, J. R., \& Daniels, L. B. (1999). Conceptualizing critical thinking. Journal of Curriculum Studies, 31(3), 285-302.

Bailin, S. R. (2002). Critical thinking and science education. Science \& Education, 11(4), 361-375.

Bagalová, L., Bizíková, L., \& Fatulová, Z. (2014). Komparatívna analýza vzdelávacieho systému v Slovenskej republike a vo vybraných ázijských krajinách. Bratislava: ŠPú.

Bean, J. C. (1996). Engaging ideas - The professor's guide to integrating writing: Critical thinking and active learning in the classroom. San Francisco: Jossey-Bass.

Bloom, B., Engelhart, M. D., Furst, E. J., Hill, W. H., \& Krathwohl, D. R. (1956). Taxonomy of educational objectives: The classification of educational goals. Handbook 1: Cognitive domain. New York: Longman Green.

Boekaerts, M., Pintrich, P. R., \& Zeidner, M. (2000). Handbook of self-regulation. New York: The Guilford Press.

Boekaerts, M. (2005). Self-regulation in the classroom: A perspective on assessment and intervention. Applied Psychology: An International Review, 54(2), 199-231.

Bonk, C. J., \& Smith, G. S. (1988). Alternative instructional strategies for creative and critical thinking in the accounting curriculum. Journal of Accounting Education, 16(2), 261-293.

Bransford, J. D., \& Stein, B. S. (1984). The ideal problem solver: A guide for improving thinking, learning and creativity. San Francisco: Freeman.

Bruner, J. S. (1960). The process of education. Cambridge: Harvard University Press.

Case, R. (2005). Moving critical thinking to the main stage. Education Canada, 45(2), 45-49. 
20 Center for Critical Thinking. (2006). A brief history of the idea of critical thinking. Rohnert Park, CA: Sonoma State University.

Cross, D. R., \& Paris, S. G. (1988). Developmental and instructional analyses of children's metacognition and reading comprehension. Journal of Educational Psychology, 80(2), 131-142.

Čavojová, V. (2016). O čom je reč, ked' hovoríme o racionalite a kritickom myslení. In V. Čavojová, et al. (Eds.), Rozum: návod na použitie. Psychológia racionálneho myslenia (s. 69-87). Bratislava: Iris.

Čavojová, V., \& Jurkovič, M. (2017). Comparison of experienced vs. novice teachers in cognitive reflection and rationality. Studia Psychologica, 59(3), 100-112.

Dewey, J. (1916). Education and democracy. New York: MacMillan.

Dillenbourg, P., Baker, M., Blaye, A., \& O'Malley, C. (1996). The evolution of research on collaborative learning. In E. Spada \& P. Reiman (Eds.), Learning in humans and machine: Towards an interdisciplinary learning science (s. 189-211). Oxford: Elsevier.

Elder, L., Paul, R. W., \& Cosgrovem, R. (2013). Online critical thinking basic concepts test. Dostupné z http://www.criticalthinking.org/pages/online-critical-thinking-basic-concepts-test/679

Ennis, R. H. (1985). A logical basis for measuring critical thinking skills. Educational Leadership, 43(2), 44-48.

Ennis. R. H., Millman, J., \& Tomko, T. N. (1985). Cornell critical thinking test level $X$ \& level Z: Manual. Seaside, CA: Midwest Publication.

Ennis. R. H., \& Millman, J. (2005). Cornell critical thinking test level Z. Seaside, CA: The Critical Thinking Co. New York.

ENQA. (2009). Normy a smernice na zabezpečovanie kvality $v$ európskom priestore vysokoškolského vzdelávania. Helsinky: Európska asociácia na zabezpečovanie kvality v oblasti vysokoškolského vzdelávania.

Facione, P. A. (1990). Critical thinking: A statement of expert consensus for purposes of educational assessment and instruction: Research findings and recommendations. Fullerton: California State University.

Fisher, R. (1997). Učíme děti myslet a učit se. Praha: Portál.

Ferencová, J. (2017). Príprava študentov učitel'ských študijných programov na rozvoj hodnotiaceho myslenia žiakov. Edukácia, 2(2), 52-61.

Ferencová, J., \& Šut'áková, V. (2011). Metódy rozvoja učebných kompetencií (k celoživotnému učeniu sa) v školskej edukácii. Didaktika, 2(4), 6-13.

Feuerstein, R., Rand, Y., Hoffman, M. B., \& Miller, R. (1996). Instrumental enrichment. An intervention program for cognitive modifiability. Baltimore: University Park Press.

Gavora, P. (1995). Kritické myslenie - prehl'ad situácie v zahraničí. In Z. Kolláriková (Ed.), Výchova ku kritickému mysleniu (s. 7-22). Bratislava: ŠPú.

Gavora, P. \& \& Matúšová, P. (2010). Sonda do čitatel'skej gramotnosti vysokoškolských študentov. Pedagogika, 1(3), 183-196.

Gardner, H. (1983). Frames of mind: The theory of multiple intelligences. New York: Basic Books.

Gažovič, O. (2017). Ako nesadnút' každému na lep. Dobrá škola, 9(4), 7.

Glaser, E. M. (1941). An experiment in the development of critical THINKING. Columbia: University.

Glaser, E. M. (1985). Critical thinking: Educating for responsible citizenship in a democracy. National Forum, 65, 24-27.

Halpern, D. F. (1998). Teaching critical thinking for transfer cross domains: Dispositions, skills, structure training and metacognitive monitoring. American Psychologist, 53, 449-455.

Halpern, D. F. (2012). Halpern critical thinking assessment: Test manual. Mödling: Schuhfried. Ištvan, I. (2016). Vybrané kapitoly z didaktiky. Prešov: Prešovská univerzita.

JQI. (2004). Shared Dublin descriptors for the Bachelor's, Master's and Doctoral awards. Dostupné z https://www.vitae.ac.uk/policy/dublin-descriptors-for-doctorate-mar-2004 -vitae.pdf/@@download/file/Dublin-descriptors-for-doctorate-Mar-2004-Vitae.pdf

Kant, I. (1979). Kritika čistého rozumu. Bratislava: Pravda. 
Kennedy, M., Fisher M. B., \& Ennis, R. H. (1991). Critical thinking: Literature review and needed research. Hillsdale: Lawrence Erlbaum.

Knapík, J. (2013a). Inovatívne metódy v predmete NV. In J. Jenčo (Ed.), Inovačné vyučovacie metódy (s. 47-54). Prešov: Michal Vaško.

Knapík, J. (2013b). Demokratická klíma triedy - dôležitý prvok pri výchove žiakov. Vychovávatel', 62(3-4), 19-22.

Knapík, J. (2014). Dramatická výchova vo vyučovaní náboženskej výchovy. In J. Jenčo (Ed.), Inovačné vyučovacie metódy a ich aplikácii (s. 181-203). Prešov: Michal Vaško.

Knapík, J. (2015). Hodnotenie štúdia na teologickej fakulte bežnými študentmi. In L. Danielová \& J. Schmied (Eds.), Sborník z mezinárodní vědecké konference ICOLLE 2015 (s. 290). Brno: Mendelova univerzita $v$ Brně.

Knapík, J. (2016). Hodnotenie medziludských vzt’ahov študentov vo vysokoškolskom prostredí. In J. Malach, Z. Sikorová, N. Sklenářová, \& M. Kocór (Eds.), Vnitřní evaluace kvality výuky v terciárním vzdělávání (s. 220-229). Ostrava: Ostravská univerzita.

Kolláriková, Z. (1995). Model kritického myslenia a zásady jeho rozvoja. In Z. Kolláriková (Ed.), Výchova ku kritickému mysleniu: teória a prax (s. 23-42). Bratislava: Univerzita Komenského.

Koníčková, J. (2010/2011). Metódy a aktivity podporujúce čítanie s porozumením a rozvoj čitatel'skej gramotnosti žiakov. Naša škola, 16(10), 32-37.

Kosová, B., \& Porubský, Š. (2011a). Transformačné premeny slovenského školstva po roku 1989. Banská Bystrica: Univerzita Mateja Bela.

Kosová, B., \& Porubský, Š. (2011b). Slovenská cesta transformácie edukačného systému po roku 1989 na príklade primárneho vzdelávania a prípravy jeho učitel’ov. Pedagogická orientace, 1(21), 35-50.

Kosová, B. (2017). Učitelia v reformách školy a kurikula. Edukácia, 1(2), 126-138.

Kosturková, M. (2012a). Možnosti využitia stratégie E-U-R v edukácii. Pedagogické rozhl'ady, 21(1/2), 1-5.

Kosturková, M. (2012b). Kriticky mysliaci učitel' v roli vychovávatel'a a sprievodcu žiakov pre budúcnost'. Vychovávatel', 61(1/2), 39-42.

Kosturková, M. (2013a). Stav kritického myslenia žiakov stredných škôl. Didaktika, 4(2), 11-15.

Kosturková, M. (2013b). Kritické myslenie pedagógov stredných škôl. Pedagogika, 4(4), 283-297.

Kosturková, M. (2016). Kritické myslenie v edukačnej praxi na Slovensku. Prešov: Rokus.

Kosturková, M. (2017a). Rozvoj schopnosti tvorit’ otázky - súčast' výchovy ku kritickému mysleniu. Manažment školy v praxi, 12(7/8), 2-6.

Kosturková, M. (2017b). Zhodnotenie vysokoškolskej prípravy budúcich učitelov vo vzt'ahu k rozvoju ich vyšších myšlienkových operácií. Edukácia, 2(2), 91-102.

Kosturková, M. (2017c). Experimentálne overenie schopnosti študentov učitel'stva tvorit' otázky. Edukácia,2(1), 139-148.

Kotrč, D. (2009). Kritické myslenie. Acta humanica, (3), 272-275.

Kubalíková, A. (2015). Možné inovácie v profesijnom rozvoji učitel'ov. Pedagogika, 6(1), 7-20.

Kuhn, D. (1991). The skills of argument. Cambridge: Cambridge University Press.

Lai, E. R. (2011). Critical thinking: A literature review. Dostupné z http://images.pearsonassessments.com/images/tmrs/CriticalThinkingReviewFINAL.pdf

Lawson, T. J., 1999. Assessing psychological critical thinking as a learning outcome for psychology majors. Teaching of Psychology, 26(3), 207-209.

Lesáková, D. (2009). Prieskum uplatňovania ECTS v doktorandskom štúdiu na univerzitách v SR. In D. Filkornová (Ed.), Aktuálny stav v implementácii ECTS na vysokých školách: zborník z konferencie Bratislava, 21. apríla 2009 (s. 27-34). Bratislava: Slovak Academic Association for International Coopertion.

Lesáková, D. (2013). Implementácia salzburských princípov v doktorandskom vzdelávaní. Academia: súčasnost' a perspektíva vysokých škôl, 24(3), 14-21.

Lewis, A., \& Smith, D. (1993). Defining higher order thinking. Theory into Practice, 32(3), 131-137. 
22 Ligoš, M., 2008. Slovenčina v kontexte nových výziev. In L. Liptáková \& M. Klimovič (Eds.), Inovácie vo vyučovaní jazyka a literatúry (s. 43-58). Prešov: Prešovská univerzita.

Lipman, M. (1988). Critical thinking: What can it be? Educational Leadership, 46(9), 38-43.

Ludvigová, I. (2012/2013). Čitatel'ská a literárna gramotnost' detí v predprimárnom vzdelávaní. Naša škola, 16(4), 40-44.

Mareš, J. (2013). Přehledové studie: jejich typologie, funkce a způsob vytváření. Pedagogická orientace, 23(4), 427-454.

Martinez, M. E. (2006). What is metacognition? Phi Delta Kappan, 87(9), 696-699.

Marzano, J. R., Pickering, D. J., Arredondo, D., Blackburn, G., Brandt, R., Moffett, C., ... Whisler, J. S. (1997). Dimensions of learning: Teacher's manual, 2nd ed. Denver: MCREL.

McPeck, J. E. (1990). Critical thinking and subject specificity: A reply to Ennis. Educational Researcher, 19(4), 10-12.

Mertová, N. (2015). Metaforické modelovanie a jeho kognitívny potenciál v politickom diskurze. In Hladanie ekvivalentnosti VIII (s. 229-236). Prešov: FF Prešovskej univerzity v Prešove.

Ministerstvo školstva a vedy SR (1994). Konštantín: Národný program výchovy a vzdelávania. Štátna politika výchovy a vzdelávania $v$ Slovenskej republike na obdobie 1995-2015. 1. a 2. diel. Bratislava: Ministerstvo školstva a vedy SR.

Nedelová, M. (2013). Overovanie použitel'nosti problémovej úlohy ako nástroja na zist'ovanie úrovne kritického myslenia na slovenských vysokoškolákoch v projekte AHELO. In P. Fridrichová \& E. Vísmeková (Eds.), Zborník vedecko-výskumných prác doktorandov PF UMB $\checkmark$ Banskej Bystrici (s. 88-98). Banská Bystrica: Inštitút vedy a výskumu PF Univerzity Mateja Bela.

Novack, G. (1960). John Dewey's theories of education. International Socialist Review, 21(1), 229-238.

Orosová, R., \& Klimková, A. (2016). Experiential education in undergraduate teacher training and its influence on the classroom climate. The Turkish Online Journal of Educational Technology, Special Issue, 989-996. Dostupné z http://www.tojet.net/special/2016_11_1.pdf

Pasternáková, L. (2014). Inovácie na FHPV v Prešove. In P. Kónya (Ed.), Univerzita v kontexte zmien (s. 569-572). Prešov: Prešovská univerzita.

Paul, R. W. (1987). Dialogical thinking: Critical thought essential to the acquisition of rational knowledge and passions. In J. B. Baron \& R. J. Sternberg (Eds.), Teaching thinking skills (s. 251-259). New York: Lawrence Erlbaum Associates.

Paul, R. W. (1992). Critical thinking: What, why, and how? New Directions for Community Colleges, 77, 3-24.

Paul, R. W., \& Elder, L. (1992). Elements of thought. Dostupné z https: / / www.criticalthinking. org/ctmodel/logic-model1.htm

Paul, R. W., \& Elder, L. (2003). La mini-guía para el Pensamiento crítico Conceptos y herramientas. Dostupné z www.criticalthinking.org/resources/PDF/SP-ConceptsandTools.pdf

Paul, R. W., \& Elder, L. (2006). Critical thinking: The nature of critical and creative thought. Journal of Developmental Education, 30(2), 34-35.

Pavlíková, A. (2013/2014). Vplyv kritického myslenia na rozvoj tvorivosti žiakov pri práci s bájou. Naša škola, 17(7-8), 26-30.

Pavlov, I., \& Krystoň, M. (2017). Model podpory profesijného učenia a rozvoja učitel'stva. In I. Pavlov (Ed.), Kontexty podpory profesijného rozvoja učitel'stva (s. 9-47). Banská Bystrica: Belianum.

Pavlov, I., \& Šnídlová, M. (2013). Profesijný rozvoj učitelov - podnety pre modely podpory. Praha: 3P, spol. s r.o.

Petlák, E. (2012/2013). EUR - Kritické myslenie žiakov vo vyučovaní. Naša škola, 16(2), 6-11. Petlák, E. (2016a). Globalizácia a výzvy pre edukáciu. Manažment školy v praxi, 12(3), 1-5.

Petlák, E. (2016b). Úvaha nad premenou školy. Pedagogická revue, 63(1-2), 5-13.

Petranová, D. (2011). Rozvíja mediálna výchova v školách kritické kompetencie žiakov. Communication Today, 2(1), 67-83.

Petranová, D. (2013). Rozvoj kritického myslela v mediálnej výchove. Pedagogické rozhl'ady, 22(4-5), 14-17. 
Petrasová, A. (2000). Čítaním a písaním ku kritickému mysleniu. Prešov: Prešovská univerzita.

Petrasová, A. (2008). Kriticky mysliaci učitel' - tvorca kvality školy. Prešov: Rokus.

Petríková, K. (2015). Alternatívne prístupy k pedagogickému hodnoteniu vo vyučovacom procese. Edukácia, 1(2), 115-124.

Petrová, G. \& \& Kozárová, N. (2017). Relačná rovina učebných štýlov žiakov a frekvencie hierarchizácií zaznamenaných v mentálnych mapách. Pedagogická revue, 64(1), 6-25.

Piaget, J., \& Inhelderová, B. (1970). Psychologie dítěte. Praha: SPN.

Plencner, A. (2014). Critical thinking and the challenges of internet. Communication Today, $5(2), 5-18$.

Porubský, Š., Kosová, B., Doušková, A., Trnka, M., Poliach, V., Fridrichová, P., ... Simanová, L. (2014). Škola a kurikulum: Transformácia v slovenskom kontexte. Banská Bystrica: Belianum.

Porubský, Š. (2017). Reformy už radšej nie! Pohl'ad slovenských učitel'ov na premeny školského kurikula po roku 2008. In I. Ištvan, J. Ferencová, \& M. Kosturková (Eds.), Pedagogická profesia z aspektu vedy, výskumu a praxe (s. 342-356). Prešov: Prešovská univerzita.

Rovňanová, L. (2015). Profesijné kompetencie učitelov. Banská Bystrica: Belianum.

Ruisel, I. (2008). Od inteligencie k múdrosti. In D. Heller, M. Charvát, \& I. Sobotková (Eds.), Psychologické dny: Já \& my a oni. Brno: Fakulta sportovních studií MU Brno ve spolupráci s Českomoravskou psychologickou společností (s. 1-6). Dostupné z http://cmps.ecn.cz/ pd/2008/pdf/ruisel.pdf

Ruisel, I., \& Ruiselová, Z. (2011). Múdrost' v kontexte osobnosti: Problémy, fakty, otázky. Bratislava: Ústav experimentálnej psychológie SAV, Slovak Academic Press.

Sámelová, J. (2013/2014). Námety na rozvoj čitatel'skej gramotnosti na 1. stupni ZŠ. Naša škola, 17(9-10), 36-39.

Scriven, M. (1985). Critical for survival. National Forum, 65(1), 9-12.

Scriven, M. \& Paul, R. (1987). Critical thinking as defined by the national council for excellence in critical thinking. Dostupné z http: / / www.criticalthinking.org/pages/defining-critical -thinking/766

Schaffer, J. C. (1995). Teaching the multiparagraphy essay: A sequential nine-week unit. San Diego: Jane Schaffer Publications.

Schafritz, J. M., Koeppe R. P., \& Soper, E. (1988). Facts on file dictionary of education. New York: Facts on File Publications.

Schievella, P. S. (1968). Critical analysis: Language and its functions. New York: Humanities Press.

Smetanová, V., Drbalová, A., \& Vitáková, D. (2015). Implicit theories of critical thinking in teachers and future teachers. Procedia - Social and Behavioral Sciences, 171, 724-732.

Smetanová, V., Flamíková, E., \& Hrašová, L. (2015). The level of critical thinking abilities among pre-service teachers. In L. Gómez Chova, A. López Martínez, \& I. Candel Torres (Eds.), $8^{\text {th }}$ International conference of education, research and innovation (s. 5304-5310). Seville: IATED.

Sternberg, R. J. (1986). Critical thinking: Its nature, measurement, and improvement. Washington, DS: National Institute of Education.

Šnídlová, M. (2010). Riadenie kontinuálneho vzdelávania a učiaca sa škola. Pedagogické rozhlady, 19(2), 23-25.

ŠPÚ. (2015a). Štátny vzdelávací program pre gymnáziá v Slovenskej republike: ISCED 3A. Dostupné z https://edumedia-depot.gei.de/bitstream/handle/11163/1286/773380744_2011. pdf?sequence $=1$

ŠPÚ. (2015b). Profil absolventa gymnázia. Dostupné z http://www.statpedu.sk/clanky/statny -vzdelavaci-program-svp-pre-gymnazia/profil-absolventa

Šutáková, V. (2017). Podmienky rozvoja d'alšieho vzdelávania pedagogických zamestnancov v prostredí vlastnej školy. In M. Kosturková, J. Ferencová, I. Ištvan, \& L. Rovňanová (Eds.), Vybrané aspekty pedagogickej profesie. (s. 412-426). Prešov: Prešovská univerzita. Dostupné z http://www.unipo.sk/public/media/13484/Zborn\%C3\%ADk\%20z\%20konferencie.pdf 
24 Šut’áková, V., \& Ferencová, J. (2017). Komparácia didaktických spôsobilostí študentov učitelstva a učitel'ov v pedagogickej praxi. Edukácia, 2(1), 313-322.

Thayer-Bacon, B. J. (2000). Transforming critical thinking: Thinking constructively. New York, NY: Teachers College Press.

Tindal, G., \& Nolet, V. (1995). Curriculum-based measurement in middle and high schools: Critical thinking skills in content areas. Focus on Exceptional Children, 27(7), 1-22.

Turek, I., Zelina, M., \& Rosa,V. (2000). Koncepcia rozvoja výchovy a vzdelávania v Slovenskej republike na najbližších 15-20 rokov (projekt „Milénium“). Dostupné z http://www .minedu.sk/DaA/ZVaVzdel/VaVSR/milenium.rtf

Velmovská, K. (2014). Physics mistakes in movies or the possibility of developing critical thinking in physics education. Journal of Science Education, 15(1), 37-40.

Velmovská, K. (2015). Rozvíjanie kritického myslenia na vyučovní fyziky (Habilitačná práca). Bratislava: Univerzita Komenského.

Velmovská, K., \& Bartošovič, L. (2016). Developing critical thinking skills in physics classes. In G. Gibson (Ed.), Crtitical thinking: Theories, methods and challenges, (s. 1-43). New York: Nova Science Publishers.

Vetráková, M. (2014). Systém kvality vzdelávania na Univerzite Mateja Bela v Banskej Bystrici. Banská Bystrica: Belianum.

Vygotskij, L. S. (1970). Myšlení a řeč. Praha: SPN.

Watson, G., \& Glaser, E. M. (1990). Watson-Glaser critical thinking appraisal. Oxford: Psychological corporation, LTD, GB.

WEF. (2017). The future of jobs: Employment, skills and workforce strategy for the fourth industrial revolution. Dostupné z www3.weforum.org/docs/WEF_Future_of_Jobs.pdf

Williams, R. L., Oliver, R., Allin, J. L., Winn, B., \& Booher, C. S. (2003). Psychological critical thinking as a course predictor and outcome variable. Teaching of Psychology, 30(3), 220-223.

Willingham, D. T. (2007). Critical thinking: Why is it so hard to teach? American Educator, 31, 8-19. Dostupné z https://www.aft.org/sites/default/files/periodicals/Crit_Thinking.pdf

Zelina, M. (2008). S Mirónom Zelinom o školskej reforme. Pravda. Dostupné z https://spravy .pravda.sk/otazky-a-odpovede/567-s-mironom-zelinom-o-skolskej-reforme/

Zelina, M. (2016). '́udské kvality pre budúcnost'. Pedagogická revue, 63(1-2), 14-12.

Zelina, M. (2017). Autoregulácia, metakognícia a exekutívne funkcie. Psychológia a patopsychológia diet'at'a, 51(4), 223-239.

PhDr. PaedDr. Martina Kosturková, Ph.D.

Ústav pedagogiky, psychológie a andragogiky / katedra pedagogiky Fakulta humanitných a prírodných vied, Prešovská univerzita v Prešove 17. novembra 1, 08016 Prešov martina.kosturkova@unipo.sk

PaedDr. Janka Ferencová, Ph.D.

Ústav pedagogiky, psychológie a andragogiky / katedra pedagogiky Fakulta humanitných a prírodných vied, Prešovská univerzita v Prešove

17. novembra 1, 08016 Prešov janka.ferencova@unipo.sk

PaedDr. Valentína Šut'áková, Ph.D.

Ústav pedagogiky, psychológie a andragogiky / katedra pedagogiky Fakulta humanitných a prírodných vied, Prešovská univerzita v Prešove 17. novembra 1, 08016 Prešov valentina.sutakova@unipo.sk 